A post-graduate and staff seminar is already in operation. Its theme for the first term of 1964- 5 will be 'People and Cities in West Africa', while for the second term it is expected that seminars will be held on 'West African Ecology'. Opportunities exist for research, with reference to Africa in general and West Africa in particular, in sociology and social anthropology; geography (especially human and agricultural geography); history (especially economic and social history); economics; political science and government; and education.

\title{
African Literature in the Department of English, University of Ibadan
}

THE Department of English in the University of Ibadan has recently started an undergraduate course in African Literature, divided broadly into two sections-the Historical and Sociological Background and the Study of Present-day African Writers. The former includes intensive study of oral and traditional material and its relevance for the African writer. The study of African writers concentrates on writings by black Africans in English -originals or translations. Some attention is also paid to indigenous white African writers, expatriate writers on Africa, the Caribbean writers, American Negro literature, and relevant literature in English. An M.A. course will be offered in the field of African literary studies from 1965 .

The Department would welcome news of the activities, publications, vacation seminars, and field projects of Institutes and University Departments concerned with African studies, and would be glad to supply on-the-spot information about African, and especially West African, writing and its own research activities. This may be obtained from Professor D. E.S. Maxwell, Head of the Department, and Mr. O. R. Dathorne, Lecturer.

\section{University College of Rhodesia and Nyasaland: The Doke Collection}

THE private library of Professor C. M. Doke, formerly Head of the Department of Bantu Studies at Witwatersrand University, has recently been acquired by the University College Library in Salisbury. It comprises more than 3,000 books, pamphlets, and manuscripts, many of them unobtainable today, and includes a number of very rare items, first editions of classic works on Bantu philology, such as Boyce's Grammar of the Kafir Language (1834), Koelle's Polyglotta Africana (1853), and Callaway's Nursery Tales and Traditions of the Zulus (1 868); the manuscript of Torrend's Grammar of Rhodesian Tonga, and of MacMinn's BembaEnglish Dictionary and his English-Bemba Vocabulary; and hitherto unpublished grammars and dictionaries in the languages of South-Central Africa, in some cases the only ones available (such as one in Lomwe, a Nyasaland language). More than I 20 Bantu languages are represented in the collection, which is particularly strong in Shona, Nguni, Bemba, Northern Rhodesian Tonga, Nyanja, and Swahili. There are also a number of valuable collections of folklore. Many of the items have been annotated by Professor Doke, and formed the basis of his standard bibliographical work Bantu. Modern Grammatical, Phonetical and Lexicographical Studies since 1860 . The collection has been acquired through the generosity of Professor Doke himself and with the assistance of the Rockefeller Foundation; when catalogued it will be available for consultation and research not only to Africanists in SouthCentral Africa, but to scholars elsewhere in Africa and in countries overseas.

\section{The National Archives of Zanzibar}

THE National Archives and documentary records of Zanzibar date from 1840 and include the archives of the British and German Consulates, the British Residency and the Government Secretariat. Records illustrating the internal history and administration of Zanzibar and Pemba also exist in large series. In January 1964 the Zanzibar Government opened the National Archives to research workers and provided a modern fully equipped Public 